\title{
Effects of Gluteus Medius Strengthening Training Using Pressure Biofeedback Unit for Muscle Function and Balance in Stroke Patients
}

\author{
Jeong-Ju Park', Hyun-Jeong So', Won-Seob Shin ${ }^{2}$ \\ 'Department of Physical Therapy, Graduate School of Daejeon University; ${ }^{2}$ Department of Physical Therapy, College of Health and Medical Science, \\ Daejeon University, Daejeon, Korea
}

Purpose: The purpose of this study was to examine the impact of gluteus medius (GM) strengthening training using the pressure biofeedback unit for lower extremity muscle function and balance ability in stroke patients.

Methods: Twenty-seven stroke patients (14 men, 13 women) volunteered to participate in this study. They were randomly assigned to 3 groups: pressure biofeedback unit GM training, general GM training, and control group. Experimental group 1 performed GM strengthening training using PBU in the sidelying position. Experimental group 2 performed GM strengthening training without PBU in the sidelying position. The training program lasted 4 weeks (20-minute sessions, three times a week). Muscle function was assessed by measuring muscle strength and endurance, and Berg balance scale (BBS), Lateral Reach Test (LRT), and limited of stability (LOS) velocity were measured for evaluation of balance ability.

Results: Enhancement of muscle strength and endurance was significantly higher in experimental group 1 than in the other two groups $(p<0.05)$. In comparison of the balance function, experimental group 1 showed a significantly enhanced ability to balance $(p<0.05)$. After the intervention, experimental group 1 showed a significant reduction of LOS velocity in the anterior direction and affected direction $(p<0.05)$. There was no significant difference than the other two groups but a large reduction was observed.

Conclusion: These findings suggest that selective gluteus medius strengthening training using the pressure biofeedback unit is effective for lower extremity muscle function and balance ability in stroke patients.

Keywords: Pressure biofeedback unit, Gluteus medius, Strength, Endurance, Balance, Stroke

\section{서 론}

하지 근력 약화는 뇌졸중 환자에게서 나타나는 가장 흔한 증상이 다. 일반적으로 하지의 근력 약화는 마비 측 하지로의 체중지지를 방 해하고 비대칭적인 자세와 신체 불균형을 유발하여 체중 이동 능력 을 감소시킨다. 또한 다리의 기능적 움직임을 저하시켜 결과적으로 는 기립과 균형 및 보행에 어려움을 가져온다.,3 골반과 척추의 안정 성을 유지시키는 요소들은 근육 간에 균형과 지구력, 근력에 의해 좌 우되는데 엉덩관절 벌림근은 보행 과정에서 골반의 중요한 안정화 근육으로 하지의 병리학적 관계에서도 중요하게 여겨지고 있다. ${ }^{4}$ 특 히, 중간볼기근은 대표적 엉덩관절 벌림근으로서, 전체적으로는 엉 덩관절 벌림에 작용하고 몸쪽부에 따라 엉덩관절 안쪽돌림과 바깥
돌림에 기여한다. 또 보행 시 몸통 옆 굽힘의 원인이 되고 하지의 안정 화 유지와 보폭을 조절하는 역할을 한다. 중간볼기근과 작은볼기근 은 발 디딤기에 하지 전체를 체중지지하기 때문에 관절 안정성에 도 움을 주고, 무게 중심을 가쪽으로 옮길 수 있도록 작용한다. ${ }^{4,5}$ 이렇게 엉덩관절과 골반의 안정성 제공에 중요한 역할을 하는 중간볼기근 이 약화되거나 억제되면, 골반의 가쪽 전위나 하강이 유발되며 허리 통증 발생 및 기능적 저하를 일으켜 낙상의 위험이 높아지게 된다. ${ }^{6}$ 특히 뇌졸중 환자에게서 중간볼기근 약화로 인한 골반의 안정성 감 소와 조절능력의 저하는 이를 해결하기 위한 보상작용을 더욱 촉진 시킨다. ${ }^{7}$ 이는 불필요한 에너지를 소모하게 하고 정상보행을 학습할 기회를 방해한다. ${ }^{8}$ 따라서 뇌졸중 환자의 균형 능력 및 보행 향상 위 해 중간볼기근 강화가 요구되며, 여러 선행 연구들에서 다양한 엉덩 
관절 벌림근 강화 훈련을 통한 균형능력 및 보행 향상에 대한 사례들 이보고되고 있다.9-12

일반적으로 허리나 엉덩관절에 병리를 가진 사람들이 중간볼기근 강화를 위해 옆으로 누운 자세에서 엉덩관절 벌림 운동을 많이 실시 하는데, ${ }^{13}$ 이는 적절한 신경근 조절을 일으키기 위해 초기 재활프로 그램에서 사용되는 열린 사슬 운동으로서, 목표화된 중간볼기근 활 성에 효과적이라고 하였다. ${ }^{14}$ 하지만, 옆으로 누운 자세에서 엉덩관절 벌림을 하는 경우 허리네모근의 과도한 사용과 빠른 수축으로 골반 이 가쪽기울임 되는 보상작용이 발생할 수 있다.615 따라서 하지의 역 동적인 움직임 동안 골반의 안정화에 관여하는 중간볼기근의 선택 적 강화는 중요하게 여겨지며 허리 및 하지의 근골격계 재활운동 시 필요하다. 이때 발생되는 원치 않는 움직임의 조절은 운동치료 시 중 요하게 인식되고 있다.

건강한 성인을 대상으로 외재적 피드백을 적용하는 것은 운동 학 습을 촉진하는데 매우 유용한 방법으로 많은 연구를 통해 입증되었 고 그에 따른 적용 지침이 제공되어 왔다. ${ }^{16,17}$ 반면, 뇌졸중 환자의 재 활에 있어 일부 외재적 피드백의 적용이 운동 학습을 보강한다고 제 안되어 왔지만 외재적 피드백에 관해 아직 많은 부분이 연구 되지 않 았고 정보가 부족한 상태이다.16-18 뇌졸중 환자는 종종 뇌 손상으로 인하여 내재적 감각 정보를 수용하는데 어려움이 있으며, 관절 가동 범위나 근력, 운동 조절 능력의 감소를 보상하기 위해 비정상적인 운 동 패턴을 사용하는 특징이 있다. ${ }^{16}$ 외재적 피드백 제공은 수행자가 인식하지 못하는 유용한 정보를 제공하고, 잘못된 움직임을 수정하 여 올바르게 이끌어 주는 역할을 하기 때문에 뇌졸중 환자의 운동 재교육에서 보다 더 중요한 역할을 할 것이다.16-20

Cynn 등리은 엉덩관절 벌림 시 피드백에 의해 대상자가 스스로 골 반가쪽기울임를 억제하는 내적 고정 방법을 제시하였다. 이는 압력 바이오피드백 기구(pressure biofeedback unit, PBU)를 엉덩빼능선과 먼쪽부분 갈비뼈 사이의 몸통 아래에 놓아 대상자가 압력의 변화를 통해 몸의 자세 변화를 인지하도록 하는 방식으로, 운동하는 동안 원 치 않는 동작에 따른 피드백을 추가로 제공함으로써 주변 근육의 대 상작용을 감소시키고 중간볼기근의 활동을 증가시키는 원리이다.

선행 연구에서 살펴 본 바와 같이 중간볼기근 강화훈련이나 외재 적 피드백 제공을 통한 운동 학습의 효과들은 각각 보고 되었으나, 중간볼기근 강화와 외재적 피드백 운동 학습 훈련을 함께 시행하였 을 때 뇌졸중 환자의 하지 근 기능 및 균형 능력 향상에 관한 연구는 부족한 실정이다. 따라서 본 연구는 중간볼기근 강화 훈련 시 압력 바 이오피드백 기구를 통한 외재적 피드백 제공이 뇌졸중 환자의 근력, 근지구력, 그리고 균형능력 향상에 어떠한 영향을 미치는지 알아보 고자하였다.

\section{연구방법}

\section{1. 연구대상}

본 연구는 대전에 소재한 $\mathrm{D}$ 재활병원에서 입원 치료를 받고 있는 뇌 졸중 환자 중 실험에 참여하기로 동의한 27명을 선정하였으며, 선정 기준은 뇌졸중으로 유병기간이 6개월 이상인자, 엉덩관절 벌림 근력 이 Fair 이상인자, 연구자가 지시하는 내용을 이해하고 따를 수 있는 한국형 간이정신상태 판별검사(MMSE-K) 점수가 24점 이상인자로 선정하였다. 시각적 또는 청각적 결함이 있는 자, 골반 및 양 하지에 정 형 외과적 질환이 있는 자, 심각한 심혈관계 문제가 있는 자는 대상자 에서 제외하였다. 연구에 앞서 대상자에게 과정 및 방법에 대해 설명 하였고, 본 연구에 참여하기로 동의한 자들만 중재에 참여하도록 하 였다.

\section{2. 연구절차}

선정 기준에 의해 선별된 뇌졸중 환자 27 명을 $\mathrm{PBU}$ 중간볼기근 강화 군, 일반적 중간볼기근 강화군과 대조군으로 각각 9 명씩 무작위 배정 하였다. 본 연구의 중재기간은 총 4 주이다. 연구 기간 동안 모든 대상 자는 군에 상관없이 일반적인 신경계 물리치료를 30 분씩 주 5 회 실시 하였으며(대조군), $\mathrm{PBU}$ 중간볼기근 강화군과 일반적 중간볼기근 강 화군는 추가적으로 중간볼기근 강화 훈련을 20 분씩, 주 3 회 실시하 였다. 사전 평가로 근력, 근지구력, 균형능력 평가를 실시하였다. 중재 후에 사전 평가했던 항목을 재평가 하였다.

\section{3. 중재방법}

중간볼기근 강화 훈련을 위해, 각 대상자는 치료용 매트에 비마비측 이 아래쪽으로 오도록 옆으로 누워 마비측 몸통과 골반, 다리가 일직 선상에 정렬되도록 하였다. 비마비측 다리는 편안함과 안정성을 위 하여 골반의 움직임이 일어나지 않는 범위에서 엉덩관절과 무릎관절 을 굽힘 하도록 하였다. 마비측 다리는 골반이 뒤돌림 되지 않는 범위 내에서 무릎을 완전히 폄한 상태로 엉덩관절 벌림을 실시하였다(Figure $1 \mathrm{~A}, \mathrm{~B})$.

벌림 하는 다리는 환자가 최대로 움직일 수 있는 범위 내에서 움직 이도록 하였고 30 도 이상 넘어가지 않도록 하였다. 훈련단계는 엉덩 관절 벌림을 등척성(isometric) 운동으로 10 분간 실시하고, 이어서 동 심 수축과 편심 수축을 포함한 등장성(isotonic) 운동으로 10 분간 실 시하였다. 등척성 운동 시 치료사가 환자의 엉덩관절 벌림 중간 범위 를 만들어준 상태에서 자세를 유지하도록 하였고, 등장성 운동 시 능 동보조 운동으로 시행하다가 점차 독립적으로 시행해 나갔다.22

PBU (Chattanooga Stabilizer, Chattanooga Group Inc., USA)를 적용 하여 중간볼기근 강화 훈련을 시행하는 동안, 탄력 주머니(elastic bag) 

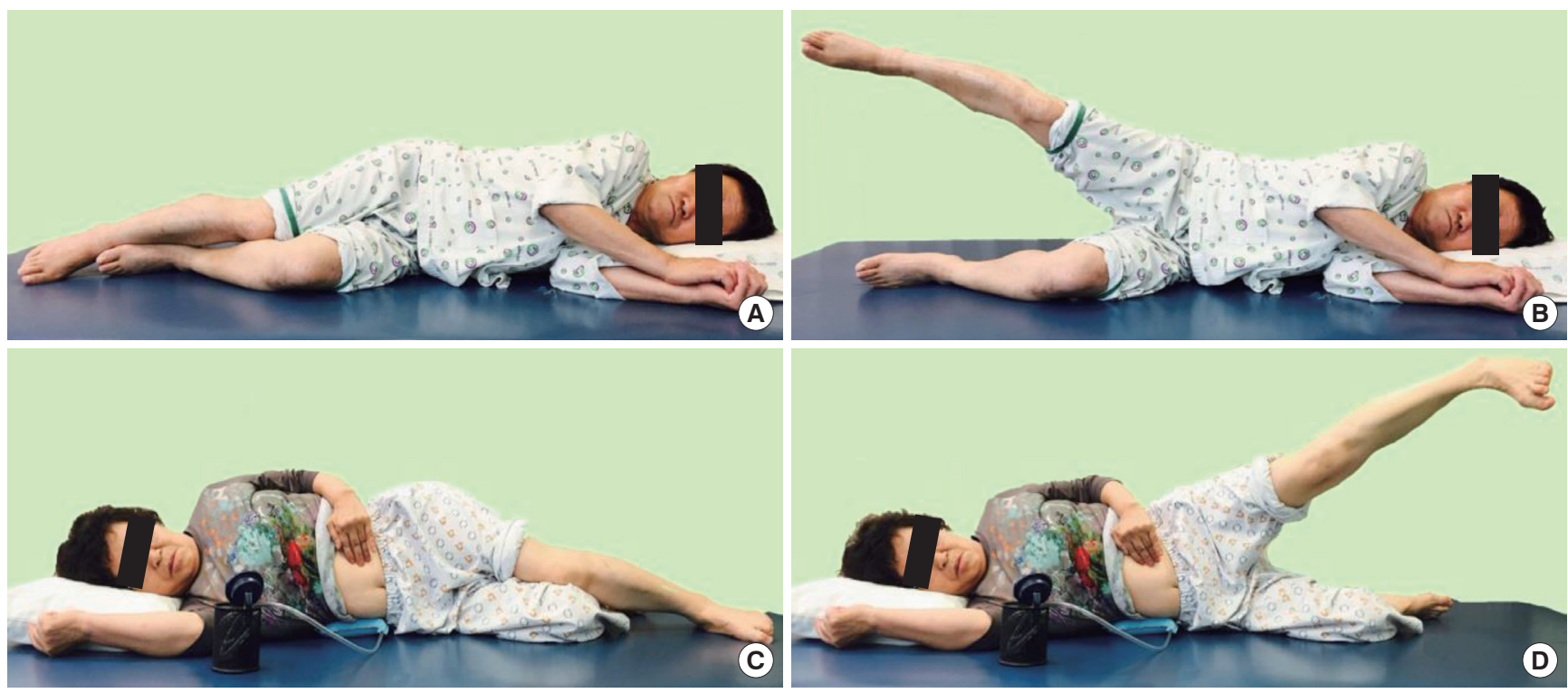

Figure 1. Gluteus medius training in side lying position. (A) starting position for general gluteus medius training, (B) ending position for general gluteus medius training, (C) starting position for gluteus medius training using pressure biofeedback unit, (B) ending position for gluteus medius training using pressure biofeedback unit.

를 매트와 허리부분 사이에 놓고, 압력을 $40 \mathrm{mmHg}$ 까지 부풀려 이를 표적 압력으로 하였다. 훈련 중 압력의 감소는 주머니와 몸통이 떨어 져서 움직이는 것을 나타내고 압력의 증가는 주머니와 몸통이 밀착 하여 움직이는 것을 나타낸다. 대상자는 PBU의 아날로그 게이지를 통해 시각 되먹임을 제공 받고, 엉덩관절을 벌림 하는 동안 표적 압력 을 유지하여 몸통의 불필요한 움직임을 억제하도록 하였다. 검사자 는 압력의 변동을 함께 모니터 하였다. 호흡으로 인한 압력의 변화는 오차범위 $\pm 5 \mathrm{mmHg}$ 로 하였다(Figure 1C, D) ${ }^{14,21}$

\section{4. 평가방법}

1) 근력 평가(Muscle Strength Testing)

중간볼기근의 근력은 휴대용 근력계(Hand-held Dynamometer, JTech Medical, USA)를 이용하여, 엉덩관절 벌림 시 등척성 수축에 대한 근 력을 측정하였다. 본 연구에서는 연속 3 회 측정한 값의 평균을 측정값 으로 사용하였다. 단위는 뉴턴(N)으로 기록하였다. 근 피로도를 피하 기 위해 대상자들은 각각의 측정 사이에 1 분간의 휴식을 취하였다.23

\section{2) 근지구력 평가(Muscular Endurance Testing)}

중간볼기근의 근지구력은 소렌슨 검사(Sorenson test) $)^{24}$ 의 원리를 이용 하여 측정하였다. 옆으로 누운 자세에서 몸통을 벨트로 고정하고 마 비측 엉덩관절을 최대 관절 가동범위의 중간위치에 놓은 자세에서 다리가 구부러지지 않고 수평면으로 떨어질 때까지의 시간(second) 을 측정 하였다. 본 연구에서는 연속 3 회 측정한 값의 평균을 측정값 으로 사용하였다. 근 피로도를 피하기 위해 대상자들은 각각의 측정
사이에 1 분간의 휴식을 취하였다. ${ }^{25}$

\section{3) 균형 능력 평가}

균형 능력을 평가하기 위하여 BioRescue, 버그균형척도(Berg Balance Scale, BBS), 옆으로 팔 뺃기 검사(Lateral Leach Test, LRT)를 이용하였다.

BioRescue (RM ingenierie, France)는 정적 자세조절 능력을 확인하 기 위해 자세동요를 측정하고, 동적 자세조절 능력을 확인하기 위해 안정성 한계를 검사하는데 사용하였다. BioRescue은 $610 \times 580 \times 10$ $\mathrm{mmn}$ 의 힘판과 연결된 컴퓨터 및 $93 \times 52 \mathrm{~cm}$ 크기의 모니터로 구성되 어 있다. 힘판의 압력감지기는 총 1,600 개로 구성되어 있으며, 압력감 지기 하나의 크기는 $10 \times 10 \mathrm{~mm}$ 이었다. 또한 힘판의 센서를 통한 데이 터의 표본수집률은 $100 \mathrm{~Hz}$ 로 얻어지도록 되어 있다.

버그균형척도는 균형에 대한 기능적 수행의 정도를 측정하기 위하 여 정적 균형능력과 동적 균형능력을 객관적으로 평가하는 척도로 서 측정자 내 신뢰도 $r=0.99$ 와 측정자 간 신뢰도 $r=0.98$ 로 신뢰도와 타당도가 인정된 평가 도구이다. 26,27

옆으로 팔 뻗기 검사는 기능적 과제 수행 시의 동적 균형 및 유연성 을 측정할 수 있는 검사로서 안정성 한계를 평가한다. 측정자 간 신뢰 도와 측정자 내 신뢰도(ICC $\geq 0.85)$ 가 높은 검사 방법으로 편 마비 환 자의 균형을 평가하기에 적합한 평가도구로 알려져 있다. ${ }^{28}$ 본 연구에 서는 연속 3 회 측정한 값의 평균을 측정값으로 사용하였다.

\section{5. 자료분석}

본 연구의 분석 방법으로 SPSS ver.19.0 프로그램을 이용하였다. PBU 
중간볼기근 강화군, 일반적 중간볼기근 강화군 그리고 대조군의 그 룹과 시점별 근력, 근지구력 그리고 균형능력을 비교분석하기 위하여 이요인 반복측정 분산분석(two-way ANOVA with repeated measurement)을 실시하였다. 또한 중재별 전후 변화량의 차이를 알아보기 위 해서 일원배치 분산분석을 실시하였고, 사후 검사는 Scheffe 검사로 실시하였다. 모든 검사에서 통계학적 유의수준은 0.05 로 하였다.

\section{결 과}

\section{1. 연구대상자의 일반적 특성}

본 연구에 참여한 연구대상자는 총 27 명으로 대상자의 일반적 특징 은 Table 1 과 같았다. 세 군간 대상자의 나이, 성별, 몸무게, 키, 발병 기 간, 이환 측, 한국판 간이 정신 상태 검사에서 유의한 차이가 없었다 $(\mathrm{p}>0.05)$ (Table 1).

\section{2. 세 군의 중재 전후 및 군 간 하지 근 기능 비교}

각 집단의 하지 근 기능을 평가하기 위해 근력과 근지구력을 측정하 였다. 중재 전후 집단 내 근력을 비교한 결과 $\mathrm{PBU}$ 중간볼기근 강화군

Table 1. General characteristics of subjects

\begin{tabular}{lcccc}
\hline & $\begin{array}{c}\text { PBU Ex. } \\
(\mathrm{n}=9)\end{array}$ & $\begin{array}{c}\text { General Ex. } \\
(\mathrm{n}=9)\end{array}$ & $\begin{array}{c}\text { Control } \\
(\mathrm{n}=9)\end{array}$ & $\chi^{2} / \mathrm{F}$ \\
\hline Age (year) & $62.1 \pm 8.6$ & $64.3 \pm 9.5$ & $69.7 \pm 10.6$ & 0.33 \\
Gender (male/female) & $6 / 3$ & $3 / 6$ & $5 / 4$ & 0.35 \\
Weight (kg) & $68.2 \pm 7.2$ & $66.8 \pm 8.0$ & $64.2 \pm 8.4$ & 0.54 \\
Height (cm) & $162.8 \pm 7.6$ & $159.9 \pm 8.2$ & $165.3 \pm 6.2$ & 0.57 \\
Time since stroke (month) & $20.6 \pm 19.4$ & $17.8 \pm 11.5$ & $25.6 \pm 21.7$ & 0.26 \\
Affected side (left/right) & $5 / 4$ & $6 / 3$ & $3 / 6$ & 0.35 \\
K-MMSE (score) & $26.7 \pm 2.5$ & $25.8 \pm 1.8$ & $25.4 \pm 2.3$ & 0.63 \\
\hline
\end{tabular}

Values are mean \pm SD.

PBU Ex., gluteus medius training using pressure biofeedback unit; General Ex., general gluteus medius training; Control, conventional physical therapy group; K-MMSE, Mini-Mental State Examination-Korean.
과 일반적 중간볼기근 강화군에서는 유의한 증가를 보였고 $(\mathrm{p}<0.05)$, 대조군에서는 유의한 변화가 없었다. 중재방법과 측정시점의 교호작 용은 유의한 것으로 나타났다 $(\mathrm{F}=16.084, \mathrm{p}<0.05)$. 세 집단 간 전후 변 화량 차이를 비교한 결과 집단 간에 유의한 차이를 보였다 $(\mathrm{p}<0.05)$. 사후검정 결과 $\mathrm{PBU}$ 중간볼기근 강화군과 일반적 중간볼기근 강화 군이 대조군에 비하여 유의한 증가를 보였다 $(\mathrm{p}<0.05)$.

중재 전후 집단 내 근지구력을 비교한 결과 $\mathrm{PBU}$ 중간볼기근 강화 군에서 유의한 증가를 보였고 $(\mathrm{p}<0.05)$, 일반적 중간볼기근 강화군과 대조군에서는 유의한 변화가 없었다. 중재방법과 측정시점의 교호작 용은 유의한 것으로 나타났다( $\mathrm{F}=5.553, \mathrm{p}<0.05)$. 그리고 세 집단 간 전후 변화량 차이를 비교한 결과 집단 간에 유의한 차이를 보였다 $(\mathrm{p}<0.05)$. 사후검정 결과 $\mathrm{PBU}$ 중간볼기근 강화군이 대조군에 비하여 유의한 증가를 보였다 $(\mathrm{p}<0.05)$ (Table 2$)$.

\section{3. 세 군의 중재 전후 및 군 간 균형능력 비교}

각 집단의 균형 능력을 평가하기 위해, 버그 균형 척도, 옆으로 팔 뻗 기 검사, 안정성 한계 속도를 측정하였다. $\mathrm{PBU}$ 중간볼기근 강화군, 일 반적 중간볼기근 강화군에서 중재 전과 비교하여 중재 후 버그 균형 척도 점수가 유의하게 증가하였으며 $(\mathrm{p}<0.05)$, 옆으로 팔 뻗기 검사는 $\mathrm{PBU}$ 중간볼기근 강화군에서만 유의한 증가를 보였다 $(\mathrm{p}<0.05)$. 중재 방법과 측정시점의 교호작용은 유의하지 않았다. 집단 간 중재 전후 의 변화량을 비교한 결과 유의한 차이를 보였다 $(\mathrm{p}<0.05)$. 사후검정 결과 버그균형척도와 옆으로 팔 뻗기 검사 모두 $\mathrm{PBU}$ 중간볼기근 강 화군이 대조군에 비하여 유의한 증가를 보였다 $(\mathrm{p}<0.05)$. 안정성 한계 검사에서 중재 전후 측정값을 비교한 결과 $\mathrm{PBU}$ 중간볼기근 강화군 은 마비측 방향에서 중재 전 2.01 에서 중재 후 1.36 으로 앞쪽방향에서 중재 전 1.79 에서 중재 후 1.26 으로 통계적으로 유의한 속도감소를 보 였다 $(\mathrm{p}<0.05)$. 중재방법과 측정시점의 교호작용은 마비측 방향 $(\mathrm{F}=5.441, \mathrm{p}<0.05)$ 과 앞쪽 방향 $(\mathrm{F}=18.310, \mathrm{p}<0.05)$ 에서 유의하게 나타 났다(Tables 3,4$)$.

Table 2. Comparison of muscle strength and endurance before and after gluteus medius training between the three groups

\begin{tabular}{|c|c|c|c|c|c|c|}
\hline & & PBU Ex. $(n=9)$ & General Ex. $(n=9)$ & Control $(n=9)$ & & \\
\hline \multirow[t]{4}{*}{ Strength (N) } & Pre-test & $22.64 \pm 4.83$ & $15.66 \pm 5.15$ & $17.21 \pm 5.82$ & Group & 4.582 \\
\hline & Post-test & $29.54 \pm 6.13$ & $22.10 \pm 4.32$ & $18.86 \pm 5.55$ & Time & $35.876^{*}$ \\
\hline & & & & & Group $\times$ Time & $16.084^{*}$ \\
\hline & Change & $6.90 \pm 4.75^{+}$ & $6.44 \pm 0.77^{+}$ & $1.64 \pm 2.70$ & & $5.227^{*}$ \\
\hline \multirow[t]{4}{*}{ Endurance (Sec) } & Pre-test & $19.84 \pm 10.75$ & $11.18 \pm 11.28$ & $12.73 \pm 7.70$ & Group & $5.500^{*}$ \\
\hline & Post-test & $38.44 \pm 20.05$ & $19.91 \pm 20.61$ & $16.31 \pm 11.43$ & Time & $45.862^{*}$ \\
\hline & & & & & Group $\times$ Time & $5.553^{*}$ \\
\hline & Change & $18.59 \pm 11.49^{+}$ & $8.72 \pm 13.26$ & $3.58 \pm 5.10$ & & $3.660 *$ \\
\hline
\end{tabular}

+Significant difference with General Ex.; ${ }^{*}$ Significant difference with Control.

${ }^{*} \mathrm{p}<0.05$.

PBU Ex., gluteus medius training using pressure biofeedback unit; General Ex., general gluteus medius training; Control, conventional physical therapy group. 
Table 3. Comparison of balance ability before and after gluteus medius training between the three groups

\begin{tabular}{|c|c|c|c|c|c|c|}
\hline & & PBU Ex. $(n=9)$ & General Ex. $(n=9)$ & Control $(n=9)$ & & \\
\hline \multirow[t]{4}{*}{ BBS (Score) } & Pre-test & $46.43 \pm 7.68$ & $38.29 \pm 13.49$ & $44.71 \pm 5.22$ & Group & 1.429 \\
\hline & Post-test & $50.14 \pm 4.81$ & $39.86 \pm 12.55$ & $45.14 \pm 5.08$ & Time & $18.182^{*}$ \\
\hline & & & & & Group $\times$ Time & 3.359 \\
\hline & Change & $3.71 \pm 3.55^{+}$ & $1.57 \pm 1.40$ & $0.43 \pm 0.79$ & & $3.858^{*}$ \\
\hline \multirow[t]{4}{*}{ LRT (cm) } & Pre-test & $12.93 \pm 1.47$ & $11.73 \pm 3.56$ & $11.11 \pm 2.38$ & Group & 2.710 \\
\hline & Post-test & $15.03 \pm 1.72$ & $12.63 \pm 4.03$ & $10.94 \pm 3.18$ & Time & 5.186 \\
\hline & & & & & Group $\times$ Time & 2.407 \\
\hline & Change & $2.10 \pm 1.70^{\ddagger}$ & $0.90 \pm 1.11$ & $-0.17 \pm 1.92$ & & 3.480 * \\
\hline
\end{tabular}

${ }^{+}$Significant difference with General Ex.; ${ }^{\ddagger}$ Significant difference with Control.

${ }^{*} \mathrm{p}<0.05$.

PBU Ex., gluteus medius training using pressure biofeedback unit; General Ex., general gluteus medius training; Control, conventional physical therapy group; BBS, Berg Balance Scale; LRT, Lateral Reach Test.

Table 4. Comparison of LOS velocity before and after gluteus medius training between the three groups

\begin{tabular}{|c|c|c|c|c|c|c|}
\hline & & PBU Ex. $(n=9)$ & General Ex. $(n=9)$ & Control $(n=9)$ & & \\
\hline \multirow[t]{4}{*}{ Paretic side velocity (cm/s) } & Pre-test & $2.01 \pm 0.75$ & $1.86 \pm 0.71$ & $1.76 \pm 0.62$ & Group & 0.298 \\
\hline & Post-test & $1.36 \pm 0.53$ & $1.96 \pm 0.37$ & $1.74 \pm 0.58$ & Time & 2.959 \\
\hline & & & & & Group $\times$ Time & $5.441^{*}$ \\
\hline & Change & $-0.66 \pm 0.54^{+}$ & $0.10 \pm 0.65$ & $-0.01 \pm 0.30$ & & $4.314^{*}$ \\
\hline \multirow[t]{4}{*}{ Non-paretic side velocity $(\mathrm{cm} / \mathrm{s})$} & Pre-test & $1.79 \pm 0.79$ & $1.91 \pm 0.82$ & $2.09 \pm 0.76$ & Group & 0.042 \\
\hline & Post-test & $1.71 \pm 0.86$ & $1.81 \pm 0.88$ & $1.61 \pm 0.94$ & Time & 1.162 \\
\hline & & & & & Group $\times$ Time & 0.207 \\
\hline & Change & $-0.07 \pm 0.59$ & $-0.10 \pm 1.00$ & $-0.47 \pm 0.16$ & & 0.385 \\
\hline \multirow[t]{4}{*}{ Ant. Velocity (cm/s) } & Pre-test & $1.79 \pm 0.53$ & $1.67 \pm 0.58$ & $2.16 \pm 0.81$ & Group & 1.301 \\
\hline & Post-test & $1.26 \pm 0.47$ & $1.70 \pm 0.48$ & $1.57 \pm 0.62$ & Time & $10.086^{*}$ \\
\hline & & & & & Group $\times$ Time & $18.310^{*}$ \\
\hline & Change & $-0.07 \pm 0.59$ & $-0.10 \pm 1.01$ & $-0.47 \pm 1.16$ & & 0.385 \\
\hline \multirow[t]{4}{*}{ Post. Velocity (cm/s) } & Pre-test & $1.56 \pm 0.52$ & $2.00 \pm 0.95$ & $2.06 \pm 1.01$ & Group & 1.614 \\
\hline & Post-test & $1.36 \pm 0.57$ & $1.51 \pm 0.48$ & $1.69 \pm 0.54$ & Time & 4.315 \\
\hline & & & & & Group $\times$ Time & 0.263 \\
\hline & Change & $-0.20 \pm 0.51$ & $-0.49 \pm 0.65$ & $-0.37 \pm 1.14$ & & 0.220 \\
\hline
\end{tabular}

${ }^{+}$Significant difference with General Ex.; ${ }^{*}$ Significant difference with Control.

${ }^{*} p<0.05$.

PBU Ex., gluteus medius training using pressure biofeedback unit; General Ex., general gluteus medius training; Control, conventional physical therapy group; LOS, limited of stability.

고 찰

본 연구는 뇌졸중 환자의 균형능력에 있어 필수적인 중간볼기근의 근 기능 회복을 위하여 중간볼기근 강화 훈련 시 압력 바이오피드백 기구를 통한 외재적 피드백 제공이 뇌졸중 환자의 근력, 근지구력, 그 리고 균형능력 향상에 어떠한 영향을 미치는지 알아보고자 하였다.

일반적으로 중간볼기근을 강화시키기 위해 옆으로 누운 자세에서 엉덩관절 벌림 운동을 실시한다. 이 자세는 골반 근육을 강화시키는 여러 운동 프로그램 중 가장 높은 중간볼기근 활성도를 보이는 자세 이며, ${ }^{29}$ 목표화된 중간볼기근 활성에 효과적이라 하였다. ${ }^{14}$ 본 연구에 서 뇌졸중 환자를 대상으로 옆으로 누운 자세에서 중간볼기근 강화
훈련을 실시한 결과 중간볼기근 근력과 근지구력에서 유의한 향상을 보였다 $(\mathrm{p}<0.05)$. 옆으로 누운 자세에서 엉덩관절 벌림을 통한 중간볼 기근 강화 훈련 시 흔히 골반의 가쪽 기울임을 이용한 보상 작용을 경험하고 지연된 중간볼기근 활성도를 보인다. 중간볼기근의 적절한 동원을 촉진시키기 위한 치료 프로토콜이 제시되어 왔고, Cynn 등21 에 따르면 압력 바이오피드백 기구를 이용한 허리부위 안정화가 같 은 쪽 골반 기울임을 감소시켜 중간볼기근 활성도의 유의한 향상를 가져왔다고 하였다. Lee 등 30 은 엉덩관절 벌림 시 압력 바이오피드백 기구와 골반 벨트를 적용한 선택적 중간볼기근 강화가 근 활성도에 유의한 향상을 보였다고 하였다. 본 연구에서 $\mathrm{PBU}$ 중간볼기근 강화 군과 일반적 중간볼기근 강화군 모두 대조군에 비해 근력의 유의한 
증가를 보였고, 특히 $\mathrm{PBU}$ 중간볼기근 강화군은 중재 후 근력과 근지 구력 모두에서 더 큰 변화량을 보였다. 이러한 결과는 압력 바이오피 드백 기구의 사용이 엉덩관절 벌림 시 근활성도 및 골반 가쪽 기울임 에 미치는 영향을 알아본 선행 연구와 유사한 결과를 보인다고 할 수 있다. ${ }^{21}$ 따라서 압력 바이오피드백 기구가 뇌졸중 환자에게 몸통 안 정성에 관한 적절한 피드백을 제공했으며, 이를 통해 중간볼기근의 목표화된 훈련이 가능했다고 설명할 수 있다.

엉덩관절 벌림근은 보행 시 디딤기에 몸통과 하지의 안정성을 조 절하는데 중요한 역할을 하고, 벌림근의 근력약화는 관상면에서의 안정성을 감소시켜 몸통의 가쪽 굽힘을 일으키는 원인이 된다. 또한, 보행 시 신체 균형을 분석하였을 때 엉덩관절 벌림근은 관상면에서 신체의 가쪽 균형 유지에 중요하다. ${ }^{6} \mathrm{Kim}$ 등 ${ }^{9}$ 의 연구에서 탄력밴드를 이용한 엉덩관절 벌림근 강화 운동은 정적 균형 능력에 영향을 주었 다. Powers ${ }^{5}$ 는 뇌졸중 환자의 마비측 엉덩관절 벌림근의 강화훈련이 신체의 가쪽면 안정성을 높여 동적 균형 능력을 증가시킨다고 하였 다. Mercer 등 ${ }^{10}$ 은 뇌졸중 환자의 엉덩관절 벌림근 강화 운동이 양 하 지의 대칭적인 체중이동을 가능하게 하고 가쪽으로의 균형 조절 능 력를 증가시켰다고 보고하였다. 이러한 연구들은 뇌졸중 환자의 신 체 안정성에 있어서 엉덩관절 벌림근이 가쪽으로의 몸통중심 이동 을 가능하게 하고 가쪽 균형능력에 영향을 주어 환자의 몸통 조절의 향상과 균형 능력에 중요한 역할을 하는 것을 보여준다. 본 연구에서 버그균형척도, 옆으로 팔 뻗기 검사는 $\mathrm{PBU}$ 중간볼기근 강화군과 일 반적 중간볼기근 강화군 내에서 중재 전·후 모두 유의하게 증가된 결 과를 나타내었다 $(\mathrm{p}<0.05)$. 세 집단간 중재 전후 변화량을 비교한 결 과, 버그균형척도와 옆으로 팔 뻗기 검사에서 $\mathrm{PBU}$ 중간볼기근 강화 군이 가장 높은 변화량을 보였다. 이 결과를 통해 $\mathrm{PBU}$ 를 적용한 중 간볼기근강화 훈련이 정적. 동적 균형에 영향을 미친다는 결과를 알 수있다.

한편, 뇌졸중 환자의 운동 학습과 관련된 외재적 피드백 사용에 대 한 선행 연구 결과들은 균형 훈련 시 자신의 체중 분포에 대한 시각 적 피드백을 제공 받은 경우 균형 능력이 향상되는 것으로 나타났 다. ${ }^{31}$ Van Vliet 등 ${ }^{18}$ 은 시각적 피드백이 뇌졸중 환자의 균형능력을 향 상시켰다고 하였고 청각적 피드백 또한 앉고 일어서기(sit-to-stand) 능 력을 향상시켰다고 하였다. Thikey 등 16 은 보행재활 동안 제공된 조기 시각적 피드백 제공이 뇌졸중 환자의 움직임 향상과 함께 재활 시 움 직임에 대한 이해력을 향상시켰다고 하였다. 본 연구에서는 시각적 피드백을 제공한 균형 훈련을 직접적으로 시행하지 않았으나 압력 바이오피드백 기구를 적용한 피드백 제공이 세 그룹 간 운동 조절 능 력에 어떠한 영향을 미쳤는지 알아보기 위해 안정성 한계 속도를 비 교하였고 그 결과 $\mathrm{PBU}$ 중간볼기근 강화군이 훈련 전후 마비측과 앞 쪽방향으로 유의한 속도감소를 보였다 $(\mathrm{p}<0.05)$. 이러한 결과는 기존
의 엉덩관절 벌림근이 디딤기에 관상면과 수평면에서의 안정성을 제 공함으로써 몸통이 앞쪽으로 쏠리거나 가쪽으로 무너지지 않도록 조절하는 역할을 하는 것을 지지하는 결과라고 할 수 있다. 세 집단 간 중재 전후 변화량을 비교한 결과 유의한 차이는 없었으나 $\mathrm{PBU}$ 중 간볼기근 강화군이 일반적 중간볼기근 강화군과 대조군 보다 상당 한 속도 감소를 보였다. 이러한 결과는 압력 바이오피드백 기구를 적 용한 중간볼기근 강화 훈련이 마비측 하지의 움직임 시 적절한 신경 근 조절을 통해 안정성 한계를 넘어 균형이 무너지는 것을 미세하게 조절하는 것이라고 할 수 있다.

본 연구의 제한점은 연구대상자 수가 적고 중재 기간이 짧아 모든 뇌졸중 환자들에게 일반화시키기 어려웠다. 또한 추적연구가 이루어 지지 않아 효과가 지속되었는지 확인하지 못하였으며 생체 역학적 변수를 검사하지 못하였다. 따라서 앞으로의 연구에서는 많은 대상 자들을 모집하여 압력 바이오피드백 기구를 적용한 중간볼기근 강 화훈련이 관절각도, 근 활성도, 근 피로도 평가와 같은 생체역학적인 변수에 미치는 영향에 관한 연구가 필요하겠다.

본 연구에서는 $\mathrm{PBU}$ 중간볼기근 강화군이 일반적 중간볼기근 강 화군과 대조군 보다 중간볼기근 의 근력, 근지구력에 유의한 향상을 가져왔고 버그균형척도와 옆으로 팔 뻗기 검사에서 유의한 증가를 보이면서 정적, 동적 균형능력의 향상을 보였다. 또한 $\mathrm{PBU}$ 중간볼기 근 강화군은 중재 전후 유의한 안정성 한계속도 감소를 보였다. 그룹 간 유의한 차이는 없었으나 상당한 속도감소를 보이면서 신경근 조 절 능력의 향상을 보였다. 이러한 결과를 통해 뇌졸중 환자에게 하지 근 기능과 균형능력 향상을 위해 압력 바이오피드백 기구를 이용한 선택적 중간볼기근 강화가 효과적이라고 제안할 수 있겠다.

\section{REFERENCES}

1. Canning B, Sanchez G. Considering powered mobility for individuals with stroke. Top Stroke Rehabil. 2004;11(2):84-8.

2. Bobath B. Adult hemiplegia, evaluation and treatment. 3rd ed. London, Butterworth-Heinemann, 1990:16-57.

3. Yang DJ, Park SK, Kang JI et al. Effects of changes in postural alignment on foot pressure and balance of patients with stroke. J Kor Phys Ther. 2014;26(4):226-33.

4. Neumann DA. Kinesiology of the musculoskeletal system, foundations for rehabilitation. 2nd ed. St. Louis, Missouri, Mosby, 2010:465-519.

5. Powers CM. The influence of abnormal hip mechanics on knee injury, a biomechanical perspective. J Orthop Sports Phys Ther. 2010;40(2):42-51.

6. Sahrmann S. Diagnosis and treatment of movement impairment syndromes. St. Louis, Missouri, Mosby, 2002:121-90.

7. Granat MH, Maxwell DJ, Ferguson AC et al. Peroneal stimulator, evaluation for the correction of spastic drop foot in hemiplegia. Arch Phys Med Rehabil. 1996;77(1):19-24.

8. Smith L, Weiss E, Lehmkuhl LD. Brunnstrom's clinical kinesiology. 
Philadelphia(PA), F. A. Davis, 1996:370-422.

9. Kim YH, Park JH, Choi WJ et al. The effect of hip abductor strengthening exercise using elastic band on static balance. Korean J Orthop Manu Ther. 2009;15(1):49-57.

10. Mercer VS, Chang SH, Williams CD et al. Effects of an exercise program to increase hip abductor muscle strength and improve lateral stability following stroke, a single subject design. J Geriatr Phys Ther. 2009; 32(2):6-15.

11. Cho MK. The effects of treadmill training with functional electrical stimulation applied to the gluteus medius and tibialis anterior on lower extremity muscle strength, balance and gait in patients with stroke. Sahmyook University. Dissertation of Master's Degree. 2013.

12. Hong SI, Bang DH, Shin WS. Effects of side walking training with elastic-band on gait and balance of stroke patients. J Kor Phys Ther. 2014; 26(5):372-8.

13. Park KM, Kim SY, Oh DW. Effects of the pelvic compression belt on gluteus medius, quadratus lumborum, and lumbar multifidus activities during side-lying hip abduction. J Electromyogr Kinesiol. 2010;20(6), 1141-5.

14. McBeth JM, Earl-Boehm JE, Cobb SC et al. Hip muscle activity during 3 side-lying hip-strengthening exercises in distance runners. J Athl Train. 2012;47(1):15

15. Chaitow L. Muscle energy techniques. Elsevier Health Sciences, 4th ed. Churchill Livingstone, 2013:101-63.

16. Thikey H, Grealy M, van Wijck F et al. Augmented visual feedback of movement performance to enhance walking recovery after stroke, study protocol for a pilot randomised controlled trial. Trials. 2012;13:163.

17. Cho HS. The effect of augmented feedback type on motor learning for hemiplegic adults and healthy adults. Chonbuk National University, Dissertation of Master's Degree. 2009.

18. Van Vliet PM, Wulf G. Extrinsic feedback for motor learning after stroke, what is the evidence? Disabil Rehabil. 2006;28(13-14):831-40.

19. Park SK, Kang JY. Effects of emg-biofeedback training on functional ability and q-angle in patellofemoral pain syndrome. J Kor Phys Ther. 2014;26(2):68-73.
20. Bu KH, Oh TY. Effects of visual information on joint angular velocity of trunk and lower extremities in sitting and squat motion. J Kor Phys Ther. 2015;27(2):89-95.

21. Cynn HS, Oh JS, Kwon OY et al. Effects of lumbar stabilization using a pressure biofeedback unit on muscle activity and lateral pelvic tilt during hip abduction in sidelying. Arch Phys Med Rehabil. 2006;87(11):1454-8.

22. Lindsay DM, Maitland M, Lowe RC et al. Comparison of isokinetic internal and external hip rotation torques using different testing positions. J Orthop Sports Phys Ther. 1992;16(1):43-50.

23. Park KN, Kim HS, Choi HS et al. Agreement of manual muscle testing and test-retest reliability of hand held dynamometer for the posterior gluteus medius muscle for patients with low back pain. Phys Ther Korea. 2011;18(3):67-75.

24. Sorensen F. Physical measurements as risk indicators for low-back trouble over a one-year period. Spine. 1984;9(2):106-19.

25. McGill SM, Childs A, Liebenson C. Endurance times for low back stabilization exercises, clinical targets for testing and training from a normal database. Arch Phys Med Rehabil. 1999;80(8):941-4.

26. Berg KO, Maki BE, Williams JI et al. Clinical and laboratory measures of postural balance in an elderly population. Arch Phys Med Rehabil. 1992;73(11):1073-80.

27. Bogle Thorbahn LD, Newton RA. Use of the berg balance test to predict falls in elderly persons. Phys Ther. 1996;76(6):576-83; discussion 84-5.

28. Duncan PW, Weiner DK, Chandler J et al. Functional reach, a new clinical measure of balance. J Gerontol. 1990;45(6):M192-7.

29. Distefano LJ, Blackburn JT, Marshall SW et al. Gluteal muscle activation during common therapeutic exercises. J Orthop Sports Phys Ther. 2009; 39(7):532-40.

30. Lee DK, Moon SN, Noh KH et al. The effects of using a pressure biofeedback unit and a pelvic belt on selective muscle activity in the hip abductor during hip abduction exercise. J Korean Soc Phys Med. 2011; 6(3), 323-30.

31. Park SK, Kim JH. Effects of emg-biofeedback training on total knee replacement patients' lower extremity muscle activity and balance. J Kor Phys Ther. 2013;25(2):81-7. 